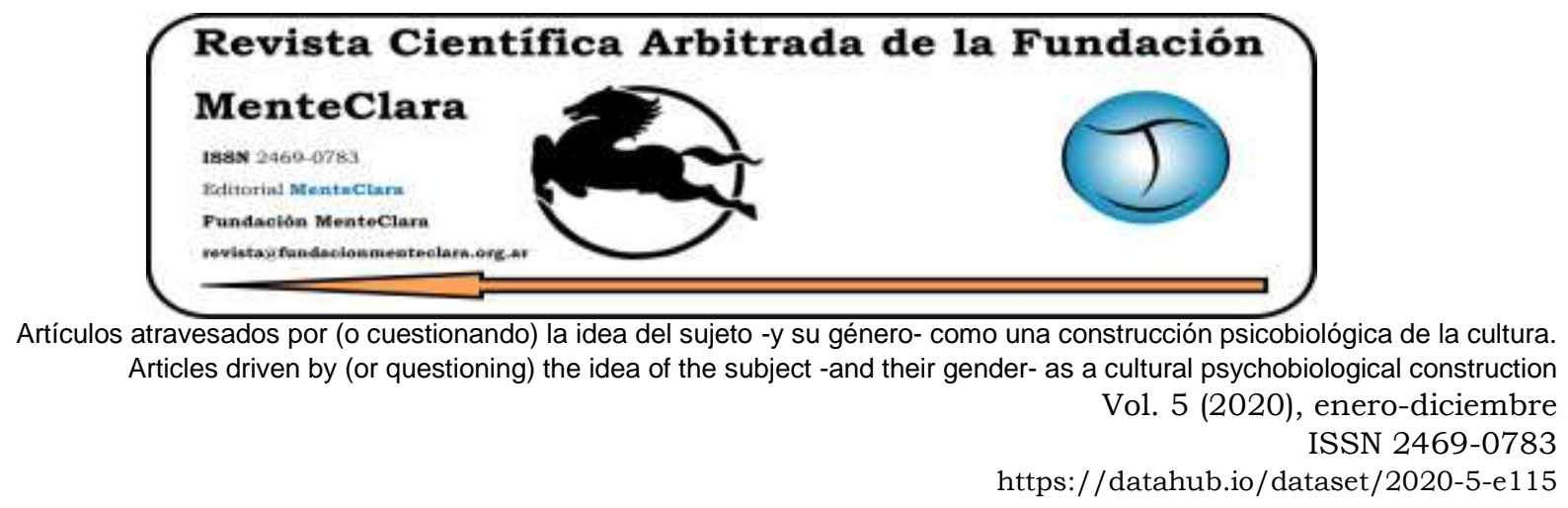

\title{
POVERTY REMOVAL MEASURES OF AMARTYA SEN AND THE SMITHIAN DILEMMA
}

\section{MEDIDAS PARA LA ELIMINACIÓN DE LA POBREZA DE AMARTYA SEN Y EL DILEMA DE ADAM SMITH}

Ratan Lal Basu rlbasu@rediffmail.com

Presidency College, Calcutta \& University of Calcutta, India.

Cómo citar este artículo / Citation: Basu R.L. (2020). "Poverty Removal Measures of Amartya Sen and the Smithian Dilemma». Revista Cientifica Arbitrada de la Fundación MenteClara, Vol. 5 (115).

DOI: https://doi.org/10.32351/rca.v5.115

Copyright: (C) 2020 RCAFMC. Este artículo de acceso abierto es distribuido bajo los términos de la licencia Creative Commons Attribution 4.0 International License (CC BY 4.0). Recibido: 15/11/2019. Aceptado: 23/11/2019 Publicación online: 06/01/2020

Conflicto de intereses: Ninguno que declarar.

\begin{abstract}
The hitherto known history of human civilization has been checkered with glorious achievements and abject injustice characterized by poverty, inequality and deprivation. The most coherent explanation of poverty and injustice is to be found in the works of Karl Marx and Frederick Engels. They associated poverty and injustice with private property, division of labour, exchange, competition, family and the State. Amartya Sen has considered pluralistic democracy as the most desirable form of government which could ensure growth with social justice along with human freedom. Although better than authoritarian forms of governing in many respects, political party based democracies are overburdened with widespread corruption based on criminal-trade union-politician alliance. Sen emphasizes the role of the mass media and awareness of the common people to break through this vicious circle and make the politicians, running the governments, work in a desirable fashion.
\end{abstract}


Unfortunately this optimistic note of Sen has come up against a serious hurdle pointed out by Adam Smith long ago. According to Smith a psychosis common to most of the people, whatever be their own positions, is that they admire the powerful and the rich (whatever be the means of their achievements) instead of the really worthy ones, viz. the honest and virtuous who has failed to achieve power and wealth. This has, in fact, spelt out a gloomy prospect for the human race.

\section{Resumen}

La historia de la civilización humana hasta ahora conocida ha sido marcada con logros gloriosos e injusticias abyectas caracterizadas por la pobreza, la desigualdad y las privaciones. La explicación más coherente de la pobreza y la injusticia se encuentra en las obras de Karl Marx y Frederick Engels. Ellos asociaron la pobreza y la injusticia con la propiedad privada, la división del trabajo, el intercambio, la competencia, la familia y el Estado. Amartya Sen ha considerado la democracia pluralista como la forma más deseable de gobierno que podría garantizar el crecimiento con justicia social junto con la libertad humana. Aunque son mejores que las formas autoritarias de gobierno en muchos aspectos, las democracias basadas en partidos políticos están sobrecargadas con una corrupción generalizada basada en la alianza criminal-sindical-política. Sen enfatiza el papel de los medios de comunicación y la conciencia de la gente común para romper este círculo vicioso y hacer que los politicos, los gobiernos, trabajen de manera deseable.

Lamentablemente, esta nota optimista de Sen se ha topado con un serio obstáculo señalado por Adam Smith hace mucho tiempo. Según Smith, una psicosis común a la mayoria de las personas, cualesquiera que sean sus propias posiciones, es que admiran a los poderosos y a los ricos (cualesquiera que sean los medios de sus logros) en lugar de los realmente dignos, a saber: El honesto y virtuoso que no ha logrado el poder y la riqueza. Esto, de hecho, ha explicado una perspectiva sombría para la raza humana.

Palabras Claves: Pobreza; desigualdad; solución marxista; solución de Amartya Sen; dilema smithiano

Keywords: Poverty; Inequality; Marxian solution; Amartya Sen's solution; Smithian dilemma 


\section{Introduction}

The new millennium emerged with the most scintillating achievement of the human race in the form of communication revolution which has enabled the process of globalization to climax into turning the entire world into a global village. Thus the most luminous gem has been added to the crown of our material achievements ever since the dawn of civilization. Unfortunately the magnificent edifice of our material glories has cast a stark shadow in the form of poverty, inequality, deprivation, exploitation, unemployment and all other forms of social injustice. In fact, the entire history of human civilization has been checkered with glorious achievements and abject injustice. All the negative aspects associated with our material progress may be summarized as poverty and deprivation. The term poverty may be looked upon in both absolute and relative sense. Both have been in existence ever since the emergence of private property and have gone on snowballing along with material progress. Absolute poverty in primitive clan societies was caused undoubtedly by lack of productive power of the clans, i.e. lack of adequate scientific and technological knowledge to exploit nature to meet their basic requirements. But this argument cannot by any means be put forward to explain the existence of poverty since the beginning of civilization and it is more so for the modern era with unbelievable achievements in the arena of industrial production. So the real cause of poverty could hardly be associated with undeveloped productive capability of the human race. It is to be sought elsewhere, viz. the heinous psychosis of the minor property owner class to exploit and enslave the majority. From this standpoint the most coherent explanation of poverty and injustice is to be found in the works of Karl Marx and Frederick Engels. They have used immaculate logic to associate poverty and injustice with private property, division of labour, exchange, competition, 
family and the State. So, according to the Marxian approach, poverty and injustice could be eliminated only in a social situation -Communism according to Marx and Engels- where the above six basic causes of poverty are completely nonexistent. The first step towards the progress to Communism is establishment of Socialism through proletarian revolution.

However, the crumbling of most of the so called socialist regimes during the late 1980s and early 1990s has raised doubt about the feasibility of the Marxian solution. The desirability of the Communistic society has also been challenged even by many staunch adherents of the Marxian doctrine. There has been a widespread frustration among the communists and adherents of the concept of socialistic pattern of society in the so called mixed economies like pre-globalization India. The consequence has been a complete about turn, blind worship of uncontrolled market economy, i.e. the so called capitalistic system. This paradigm shift has resulted in unbelievable material progress since the late 1980s, but with the dawning of the new millennium the horror of increasing poverty and deprivation has been haunting the conscientious minds. The most prominent voice that has raised protests against blind adherence to free market mechanism is that of Amartya Sen who has emphasized that to contain the maladies associated with material progress in the era of globalization, public action is essential. He has considered pluralistic democracy as the most desirable form of government which could ensure growth with social justice along with human freedom. Although better than authoritarian forms of governing in many respects, political party based democracies are overburdened with widespread corruption based on criminal-trade union-politician alliance. Sen emphasizes the role of the mass media and awareness of 
the common people to break through this vicious circle and make the politicians, running the governments, work in a desirable fashion.

Unfortunately this optimistic note of Sen has come up against a serious hurdle pointed out by Adam Smith long ago. According to Smith a psychosis common to most of the people, whatever be their own positions, is that they admire the powerful and the rich -whatever be the means of their achievements- instead of the really worthy ones, viz. the honest and virtuous who has failed to achieve power and wealth. This has, in fact, spelt out a gloomy prospect for the human race. In this article we endeavour to take up these issues. Accordingly, in the rest of this article, we are going to take up in detail the following topics: Poverty Concepts, Marxian Approach, Sen's Approach and Smithian Dilemma.

\section{Poverty Concepts}

The phenomenon of poverty has posed the most serious challenge to development efforts in the new millennium. This primeval malady is the source of many other serious maladies. In modern economic literature the question of absolute poverty has justifiably been considered as the most primary issue, although attention has also been drawn to the question of inequality, both intra-nation and inter-nation.

At present, the most pressing problem, of the third world countries comprising the overwhelming majority of world-population, has been the precarious situation generated by absolute poverty in its extreme form and, therefore, at least on the theoretical plain, the major concern of economic policy of the government of each of these countries has been to devise appropriate and fruitful means to reduce the intensity of the problem of absolute poverty. The question has also been a matter of deep concern for the developed countries, but for completely different reasons. 
Continuation of abject poverty in the third world countries generates enough provocation for the poor of these countries to resort to violence, organized or anarchic. Thus poverty in less developed countries -LDCshas both direct and indirect adverse consequences - directly by material deprivation of the majority and indirectly by paving the way for violent discontent.

Now as we turn to the question of removal of poverty, we immediately come upon the tricky question of quantitative measurement, without which it is hardly possible to frame any realistic target-oriented poverty removal policy. To this end the crudest approach considers income as the criterion of defining poverty and attempts to measure poverty by the Head Count Ratio -HCR-. In this measure at first the minimum income necessary for provision of subsistence requirements is determined. This threshold income is called the Poverty Line. At the next step, data on the number of persons with income below this critical level are collected. At the final stage this figure is expressed as a percentage of the total population of the country under consideration.

The most important question in connection with the HCR is the definition of the critical income level pertaining to the poverty line. The critical poverty line income differs from country to country depending on the variability of per capita income, structure of national income, ethnic and cultural factors that make a world of difference in the concept of subsistence requirement. Generally the poverty line income for a poor country is less than that for a relatively opulent country.

Notwithstanding these inter-country differences, the World Bank has defined a general Poverty Line for the world as $\$ 1$ per person per day at purchasing power parity. Although this may enable the World Bank to have a rough idea about overall poverty in the world, for policy framing of the LDCs, the standard may seem too high and for the highly developed 
nations, too low. The third world countries afflicted with abject poverty are compelled to set a much lower margin of income for the Poverty Line and device policies to raise income of the poor in relation to this critical level. For example, the official Poverty Line in Indian, based on minimum calorie requirements for sustenance of life, is much below the World Bank standard.

Apart from this conceptual limitation, the HCR has revealed limitations from the policy stand point as the measure fails to quantify the income gap of the poor from the Poverty Line. Thus it does not provide any guideline as to the magnitude of the total income gap to be covered if a country wants to remove poverty of a targeted segment of the poor. Moreover this measure is also a poor instrument of inter-country comparison of poverty.

The poverty gap measures have been devised to take into income shortfall of the poor from the Poverty Line. There have been various indices of this category to take into account specific aspects of poverty gap. The details of all these measures and the mathematical formulas are irrelevant for this study ${ }^{1}$.

Amartya Sen has criticized the income-based poverty measures as they fail to take account of deprivations in terms of basic amenities of life such as literacy, healthcare, safe drinking water, pollution-free atmosphere. So he has defined poverty indices based on these aspects of human living, popularly known as capability-based indices (Sen, 1984) (Sen, 1993). In this connection, the Human Poverty indices of UNDP -United Nations Development Program- are worth mentioning (UNDP, HDR 2003, pp. 342-43). Sen's approach would be taken up in a subsequent section.

\footnotetext{
${ }^{1}$ For details see Sen 1981, Sinha and Sen, Raj Kumar (eds.) 2000, pp. 193-265
} 


\section{Inequality}

In modern economic literature, attention has also been drawn to various aspects of relative poverty or inequality both in terms of income and in terms of basic amenities. The common statistical measure to quantify inequality is the Gini Coefficient derived from the Lorenz Curve ${ }^{2}$.

All surveys to quantify inequality in terms of this approach have revealed widespread inequality in terms of income, basic amenities and human development in most of the countries -irrespective of the level of economic development-. Research works have also revealed wide differences in the degree of inequality in various regions of the same country. If we look into the world scenario and compare different nations on the basis of per capita income and Human Development Index wide disparities among nations would become apparent. Time series data from the World Development Report and Human Development Report reveal widening disparities among nations over time negating all the nicely constructed growth models indicating convergence (WDR, HDR various issues).

\section{Poverty Removal Measures in LDCs}

So far as the LDCs are concerned, inequality and low level of development have combined to assign such a grave significance to absolute poverty that poverty removal has been the most crucial policy issue for all sensible governments, especially in the LDCs. The two major theoretical approaches in this direction are:

I) Trickledown Approach

II) Direct Approach

2 For various measures of inequality and the problems associated with them see Sen, 1973, 1982. 
The distinctions between these two approaches may be clarified with examples from India.

At the initial stage of planning in India it was expected that economic growth would automatically trickle down to remove the intensity of poverty at the lower strata of income. But this did not happen as most of the fruits of planned economic development had been cornered by the well to do minority magnifying the intensity of poverty and inequality. So since the Fifth Five Year Plan (1974-79) the 'trickledown approach' was abandoned and emphasis was laid on direct poverty removal measures. Since then innumerable special poverty removal programmes -like IRDP, SFDA, ILDDPAP, TADP, MNP- have been in operation (Hiraway, 1986).

No doubt, this direct attack on poverty has produced some positive results, but they have been quite inadequate considering the magnitude of poverty in this highly populated country (World Bank 1997, 1998, 1999) (Muqtada, 1990).

Since the 1990s it has been emphasized that a combination of growth and direct programme would be the best measure for poverty removal in India (Hanumantha, 1992). This may be the experience of many other third world countries. The drives of the world institutions like the UNO, IMF and the World Bank have also been in this direction. This is obvious from the exhortations in all the recent issues of the World Development Report, the Human Development Report and all other publications by the world bodies.

\section{Marxian Approach}

Marxian theory of the historical process of development of the human society gives an excellent account of the genesis of poverty and inequality. From economic standpoint Marx divides the process of development of 
human society into four major stages: primitive communism, slave society, feudalism and capitalism. He predicts that capitalism would be replaced by socialism, which again will ultimately dissolve into the utopian stage of Communism.

At the first stage, during primitive communism, poverty in the modern sense did not exist - poverty in the modern sense is meaningful only when its opposite, viz. opulence, exists-. It was simply limitation of amenities, applicable to all members of a clan, because of limited knowledge to explore natural resources to meet human demand. These clan societies were characterized by equality (Engels, 1884, Ch-IX, P.155).

Man-nature conflict gradually led to improvement in methods of production - man gradually having more and more command over Nature with its increasing knowledge. With acceleration of this process by increasing social division of labour, surplus over and above consumption requirements started emerging. And at the same time human values pertaining to fellow feeling and equality started degenerating into slavery - oppression of one class of people by another (Ibid. P. 157-160).

With the emergence of money as the most convenient medium of exchange and the emergence of the parasitic merchant class, the process of property ownership and accumulation of wealth by a few and the consequent poverty and inequality were further crystallized. (Ibid. P. 162163)

Continued material progress, made possible by increasing command over Nature, ultimately paved the way for the Industrial Revolution, which ushered in the capitalistic or bourgeois society as the controlling power of resources and production. Capitalism enhanced the pace of materialistic development but at the same time it generated more 
ruthless exploitation of the labour class turning them into proletariats. (Ibid. P. 172) (Marx and Engels 1848, Ch-1, P. 48, P. 51)

According to Marx and Engels the basic causes of oppression, exploitation, and increasing poverty and inequality along with material progress were class society and the institution of private property with the associated vices like division of labour, exchange, family, competition and the State. Let us have a brief glimpse of the Marxian view regarding these factors.

\section{Private Property}

According to Marxian world outlook, private property is the basic cause of all maladies in human society. So the task of the communists is to abolish all private property. The Primeval Sin -downfall of Adam and Eve from the Eden of Primitive Communism- begins from the emergence of 'Alienated' or 'Estranged' labour which is both cause and consequence of private property -for detail see Marx 1974, pp. 61-74-.

The corrupting influence of private property on every aspect of human living has been clearly stated by Marx (Marx 1974 p. 94).

So the process of human development, according to Marx, calls for complete abolition of private property (Marx and Engels 1848, p. 63-64) (Engels, 1969, p. 89).

Division of labour, competition, exchange, family and all other corrupting elements of society, according to Marx, have originated from the Primeval Sin, viz. Private Property and Estranged Labour (Marx, 1974, p. 73, p.91).

\section{Division of Labour and Exchange}

Marx and Engels describe how division of labour and exchange mechanism originates from private property (Engels, 1884, p. 171) (Marx 
1974, p. 113-117). They also describe clearly the adverse consequences of division of labour and exchange for the human society (Marx, 1966, p. 125). So division of labour, which is one of the major causes of class division of the society, is to be abolished (Engels, 1969, pp.93-94).

\section{Family}

Marx and Engels consider family to be one of the evils generated from private property relations and evolved through various stages of economic advancement and they opine that family would perish automatically as soon as private property is abolished (Marx and Engels 1848, p. 68-71) (Engels, 1969, p.94).

\section{Competition}

According to Marxian view, competition, another consequence of private property, has been the propelling force as well as the cause of disorder of bourgeois society. He opines that competition and monopoly are but two sides of the same coin (Marx, 1974, p. 177) (Marx, 1966, p. 130-132).

So, abolition of competition is one of the major tasks of the communists (Engels, 1969, p. 89).

\section{The State}

According to Marxian view, the Sate is an institution developed solely to protect the interests of the exploiter minority against that of the exploited majority and it is an institution that facilitates the process of exploitation. However, ultimately with the end of class antagonism, the necessity of the State would vanish and so the State would also disappear (Engels, 1975, p. 166-170). 


\section{Transition}

Although human society, according to Marx, is likely to automatically bring about Communism by the inherent contradictions, but it may take a very long time. So he opines that this process of transition towards the ultimate goal is to be hastened by means of deliberate efforts. Capitalism has already generated the force, viz. the proletariats, which can play a crucial role in accelerating this pace by overthrowing the bourgeois Sate and establish Socialistic State under the dictatorship of the proletariat and thereby pave the path towards Communism. The weapon of the proletariat is the same class struggle which has been the driving force of human history ever since the emergence of private property.

\section{Class Struggle}

According Marxian view, the driving force of human civilization has been class struggle, the relentless war between the exploiters and the exploited. This class struggle would lead to overthrow of the bourgeois State by the proletariat to bring about Socialism and ultimately pave the way to Communism, the blissful state. Thus Marxian human development consists in generating class consciousness of the proletariats and hastening the pace of relentless class struggle by deliberate efforts of the Communist Party (Marx and Engels 1848, pp. 4041).

To this end the first step is to organize the proletariats under the Communist Party and inspire them to overthrow the bourgeois State and replace it by Socialistic State under the advanced detachment of the proletariat (Stalin, 1970, p. 103) (Engels, 1975, pp. 326-27).

The ultimate goal of Marxian human development process is, however, to achieve Communism, which is completely free from private property, division of labour, exchange, family and the State. But the transition, 
after takeover of State-power by the proletariats and replacement of Bourgeois State by Socialist State, would take a long historical process. To this end the initial steps to be undertaken have been described in detail (Marx and Engels 1848, pp. 74-76).

Marx failed to realize -because of either superficial observation or myopic view or parochial attachments- that causes of poverty, inequality, exploitation and similar maladies do not lie in private property, family relations, the State or any other visible phenomenon, but it lies deep in human nature, in the unethical elements like greed, pride, jealousy etc. So, eradication of the maladies, if at all possible, is to be accomplished by some process that would reduce the prevalence of these basic vices in human mind.

Occasionally, however, Marx and Engels came down to the real causes of the maladies, e.g.:

"The only wheels which political economy sets in motion are greed and the war amongst the greedy - competition" (Marx, 1974, p. 62).

But these fleeting moments of digression to reality soon dissolved into the preaching of their invented doctrine.

The Marxian weapon to overthrow the bourgeois State is the proletariat class, the labour class forced down to the level of bare subsistence (Marx, 1974, p. 61).

This cannot, however, be denied that such proletariat class had real existence in all the nascent capitalist countries during the time of Marx -the nineteenth century-. But with technological advancement during the twentieth century, the scenario changed radically. The size of the proletarian class, 'who had nothing to lose but chains', in the capitalist countries, gradually diminished in size in course of technological progress during the twentieth century and almost vanished with the 
onset of the new millennium. The relatively better paid labourers of the modern capitalist countries could hardly be inspired to raise arms against the capitalists, unlike their proletariat brethren a century ago. Moreover, class composition in the modern capitalist countries has become extremely complex with the swelling of various grades of the middle class. This has belied the Marxian conviction that under capitalism the society would be polarized into two distinct classes: capitalists and labourers.

Unfortunately, because of his myopic vision and too much preoccupation with invented doctrines, Marx failed to grasp the future world that is to be ushered in by capitalism. So, ultimately, in the real world, Marxism degenerated into Leninism and Maoism, aiming at overthrowing the State by organizing the poverty stricken masses of the feudal and semi-feudal countries. Marx and Engels, however, had dubbed this sort of endeavour as utopian socialism (Engels, 1975 p. 293).

Marx and Engels strongly asserted that their concepts had been derived from historical facts rather than invention (Marx and Engels op. cit. Ch-2, P. 62).

Now think of the so called proletarian philosophy. The depth of knowledge and introspection required to grasp the essence of the Marxian world outlook can hardly be found among the wage-earning class. Thus it is simply a world outlook invented by the speculative faculty of a highly intelligent and well read middleclass intellectual like Karl Marx who claimed it to be springing from the historical experience of the labour class. Nothing could be more ridiculous than this.

Later Marxists were well aware of this fact and therefore felt the necessity of re-educating the labourers with Marxian theories (Stalin, 1970, p. 103). 
Now let us look closely into the ultimate goal of Marx, i.e. Communism. In such a stage of human history, there would be no private property, no family, no State, no competition, no division of labour, and no exchange (Marx, 1974, p. 91).

Men would lose their individual entity in such a stage and exist only as part of the species being -the humans- just like the trees in a forest. What a pathetic future for the human race targeted by Marx! Is it not brutal sadism to eke out such a horrible future for the human race?

\section{Sen's Approach}

In recent years Amartya Sen's contributions have assigned a new dimension to the 'economics of poverty', especially its ethical aspects. Sen's major contributions in revitalizing the non-conventional economic thought have been remarkable. He gave a new lease of life to normative economics then languishing in Arrow's 'Impossibility Theorem' (Arrow, 1951) (Sen, 1970). He also played an important role in reviving the development economics -moribund under the onslaught of aggressive neo-classicism, reemerging with renewed vigour with the up-tide of the process of globalization- by redefining economic development in terms of entitlements and capabilities ${ }^{3}$ and freedom (Sen, 1984, P.497) (Sen, 2000).

Capabilities depend, besides exchange entitlements, on provision of public goods -when market failure results in no private supply- like health, education, longevity, pollution-free environment, safe drinking water (Ibid. pp.499-500).

\footnotetext{
3 "Entitlement refers to the set of alternative commodity bundles that a person can command in a society using the totality of rights and opportunities that he or she faces... On the basis of this entitlement, a person can acquire some capabilities, i.e. the ability to do this or that (e.g. be well nourished), and fail to acquire some other capabilities" (Sen, 1984, p.497).
} 
In some of his major works, Sen and his followers have brought to the fore the role of State Policy and public action in preventing the acute manifestation of poverty, viz. famine (Drèze and Sen 1989) (Drèze, Sen and Hussain 1995) (Sen, 1981). Their general observation in this regard is that many famines occurring in India during the British period including the horrible Bengal Famine of 1943, vividly presented in novels by two great Bengali Authors- and elsewhere in modern age were mainly due to 'Entitlement-Failure' and negative State policy and/or lack of political will. Nehru, the first Prime minister of India also subscribed to this view (Nehru, 1981, p.497).

Sen appreciates the role of the present government of India in tackling famines by suitable public action and appropriate policies. In this regard he emphasizes the role of freedom of mass media and public opinion in a democratic polity as in independent India -which is absent in dictatorial countries like China- (Drèze and Sen 1989, pp. 278-79).

Sen, however, admits that dictatorial China has a better record as regards tackling chronic poverty (Sen, 1984 p.500).

Now, Sen hints at the possibility of combining the advantages of these two contrasting political systems (Ibid. p.504).

In this connection it would be worthwhile to look into the merits of various major forms of political systems as regards ensuring social justice by minimizing poverty, inequality and deprivation. Here the main contenders are centrally control systems -Dictatorship, Monarchy and Socialism- and Democracy.

Dictatorship: Historical experience of all forms of non-socialist dictatorial regimes -in the past and the present- has unraveled their 
overwhelmingly oppressive features ${ }^{4}$. We may consider for example the case of Argentina. Since independence of the Republic of Argentina from Spanish rule on July 9, 1816, the country had to experience the trauma of military dictatorship several times -1835-1852; 1930-1932; 19431946; 1955-1958; 1966-1973; 1976-1983-. The military rule served the interests of the comprador bourgeoisie, linked mainly with neoimperialism of the USA. Military presidents like Juan Manuel de Rosas (1835-52); Jorge Rafael Videla (1976-81), Leopoldo Galtieri (1981-82) were basically the stooges of the USA (Antonius, C. G. M. Robben, 2007) (McSherry, 2005). During these periods income disparity increased remarkably leading to rapid prosperity of the minority ruling class and proletarianization of the labourers, ruthless oppression of the masses, suppression of freedom of speech, mass media etc. similar is the experience of other Latin American countries, countries of Africa and Asia under dictatorial regimes.

So we rule out this form of governance.

Monarchy: Ancient Indian Texts -especially Manusmriti and Arthasastra of Kautilya5- (Basu, 2005) have laid down detailed rules and procedures to make an ideal king. Unfortunately, in the recorded history, except Asoka (Thapar, 1961) (Sastri, 1967, pp.201-48) (Kosambi 1981, pp.157-65), there is no evidence of the existence of another ideal king. The great Greek philosopher Plato conceived of a Philosopher King (Plato, 1901, pp.215-40). As regards his concept of 'Philosopher King' Immanuel Kant made an interesting observation.

\footnotetext{
${ }^{4}$ See Black 1986, Fitch and Lowenthal (eds.) 1986 for the heinous roles of dictatorial regimes in Latin America; Amitav Ghosh's novel "The Glass Place" (Ghosh 2001) portrays a vivid account of the oppressive dictatorial regime in Myanmar (Burma). 
“That 'kings will philosophize or philosophers become kings,' is not to be expected. Nor indeed is it to be desired, because the possession of power inevitably corrupts the free judgment of reason. But kings or king-like nations, who govern themselves according to laws of equality, should not allow the philosophers as a class to disappear, or to be silenced; rather should they be allowed to speak forth their maxims publicly. Nay, this is even indispensable to both for the mutual enlightenment of their functions. Nor should this process of communicating enlightenment be jealously regarded as a kind of Propagandism, because as a class the philosophers are by their nature incapable of combining into political clubs and factions." (Kant 1795, Second Supplement: Secret Article Relating to Perpetual Peace). Plato later on abandoned this idea after a bitter experience ${ }^{6}$.

So monarchy is ruled out.

Socialism: Like the Indian concept of Ideal King or Plato's Philosopher King, socialism is also a utopian concept. It differs in one respect, viz. unlike the former two forms of governance the means to achieve its goal is the violent 'class struggle'. This is the basic reason that compelled the USSR, the first and the most powerful socialist state, to revert back to capitalistic path (Basu, 1999).

Democracy: Now we are left with democracy, which, from the standpoint of human freedom, is the best conceivable form of government. We have already touched upon Amartya Sen's views about the role of public opinion and the mass media in ensuring positive changes in the society. We, also rest our ultimate hope on this form of government. But the present state of democracy in the world and the

\footnotetext{
${ }^{6}$ According to the Greek author Diogenes Laertius, Plato received an invitation from Dionysius, the king of Syracuse to turn his kingdom into Utopia and Plato readily accepted the invitation. But when Plato suggested the king either to become a philosopher himself or to relinquish power for some philosopher in order to make his kingdom a utopia, the king got infuriated with Plato and sold him to a slave trader. Fortunately Plato's disciple Anniceris appeared in time as a rescuer by repurchasing Plato from the slave trader. This disillusioned Plato prompting him to abandon his concept of 'philosopher king' (Laertius 2001, Book-3 (XIV-XVIII).
} 
global trends are not at all encouraging. The Neoclassical view, based on 'perfect competition' and 'laissez faire' doctrine and playing the ideological basis of economic policies in the modern democratic countries till the early twentieth century, revealed its serious vulnerability during the 'Great Depression' of the 1930s. Keynesian economics emerging out of the bitter experiences of the Great Depression led to an abandonment of the laissez faire doctrine permitting state-intervention in the free-market economies, although to a limited scale. In the newly independent democratic countries like India during the post-war era, pervasive stateintervention in the form of comprehensive planning, control of the private enterprises, pioneering role of the state sector in strategic fields, price control, public distribution system for food and mass consumption commodities etc., became necessary both to break through the vicious circle of backwardness and to ensure social justice. But because of the inefficiency and corruption of the political parties and the government officials, both planning and public sector enterprises in these so called 'mixed economies' came up against serious hurdles, ultimately forcing them to move towards free market economies.

During the late 20th century, there was strong opinion among economists for revival of the free-market economy, completely devoid of state-interventions (Friedman, 1980). In the meantime debacles of the socialist countries and planned mixed economies prepared grounds for the revival of Neoclassicism. The process of reversal got momentum with the spectacular communication revolution and ultimately the so called era of 'globalization' emerged.

With this background let us look into the efficacy of the democracies in ensuring social justice with progressive reduction of poverty, inequality and deprivations in the new era. 
We have already mentioned that Amartya Sen has strongly appreciated the role of public opinion and free mass media in ensuring social justice in the democratic countries.

But Sen's hopes, placed on the masses and the media to make democracy really meaningful, come up against the Smithian Dilemma.

\section{The Smithian Dilemma}

Adam Smith unequivocally explained why material achievements in the form of economic power is conceived as the best server of self interest of an individual in spite of all personal hazards associated with it. Here Smith goes deep into basic human psychology and puts forward his findings from empirical observations in this regard. An inherent nature of any human being, whatever his own position, is to praise and worship the successful and rich people, whatever immoral be the means by which this opulence has been achieved. Moreover, most people nurture in their subconscious, the hidden desire to achieve opulence and fame so as to get the praise and approbation of all and sundry.

"This disposition to admire, and almost to worship, the rich and the powerful, and to despise, or, at least, to neglect persons of poor and mean condition, though necessary both to establish and to maintain the distinction of ranks and the order of society, is, at the same time, the great and most universal cause of the corruption of our moral sentiments. That wealth and greatness are often regarded with the respect and admiration which are due only to wisdom and virtue; and that the contempt, of which vice and folly are the only proper objects, is often most unjustly bestowed upon poverty and weakness, has been the complaint of moralists in all ages" (Smith, 1759, I.III.28). 
"We desire both to be respectable and to be respected. We dread both to be contemptible and to be condemned. But, upon coming into the world, we soon find that wisdom and virtue are by no means the sole objects of respect; nor vice and folly, of contempt. We frequently see the respectful attentions of the world more strongly directed towards the rich and the great, than towards the wise and the virtuous. We see frequently the vices and follies of the powerful much less despised than the poverty and weakness of the innocent. To deserve, to acquire, and to enjoy the respect and admiration of mankind, are the great objects of ambition and emulation. Two different roads are presented to us, equally leading to the attainment of this so much desired object; the one, by the study of wisdom and the practice of virtue; the other, by the acquisition of wealth and greatness. Two different characters are presented to our emulation; the one, of proud ambition and ostentatious avidity. The other, of humble modesty and equitable justice. Two different models, two different pictures, are held out to us, according to which we may fashion our own character and behaviour; the one more gaudy and glittering in its colouring; the other more correct and more exquisitely beautiful in its outline: the one forcing itself upon the notice of every wandering eye; the other, attracting the attention of scarce anybody but the most studious and careful observer. They are the wise and the virtuous chiefly, a select, though, I am afraid, but a small party, who are the real and steady admirers of wisdom and virtue. The great mob of mankind are the admirers and worshippers, and, what may seem more extraordinary, most frequently the disinterested admirers and worshippers, of wealth and greatness" (Ibid. I.III.29).

"In equal degrees of merit there is scarce any man who does not respect more the rich and the great, than the poor and the humble. 
With most men the presumption and vanity of the former are much more admired, than the real and solid merit of the latter" (Ibid. I.III.31).

This undeniable nature of masses belies all hopes to bring back the corrupt politicians to the path of ethics and virtue. The inner discipline of all the major political parties makes it impossible for the ordinary members to protest against the mischief of the leaders. Moreover "leader worship" for Smithian psychosis makes the cadres, members and supporters of political parties to ignore the heinous activities of the leaders. The corrupt politicians also inculcate the inherent corrupt mentality of the common people. Thus the politicians get absolute freedom to do whatever best serves their personal interest even at the cost of the society and the masses.

This belies all our hopes to eradicate poverty and social injustice through the democratic system, as it exists today. But still there is hope of reforming the democratic system, making it free from the maladies that come on the path of freedom and removal of poverty, inequality and exploitation of the majority by the minority. In order to achieve this end masses are to be re-educated and awakened from the slumber of tamasik mode of living. The process of cultural evolution to this end has been detailed in another article of this author. Rabindranath Tagore, the Nobel Laureate Indian poet, has also provided a brief hint as regards awakening the masses. His view is delineated in the concluding section.

\section{Conclusion}

We are in all praise for the Sen's approach for poverty alleviation. But we also emphasize that this is but a palliative and would never remove the deep seated cause lying in human nature. On the contrary, this may make the deprived dependent on outside help and thereby get further 
submerged in vice and ignorance. Long ago, Rabindranath had warned against this attitude of helping the common people. At the same time he suggested how higher values could be inculcated among the masses.

"For this reason, the most urgent necessity in our country is not to place begging bowls at their hands, but to make them confident of their own strength, to make them realize that a man united with others is a complete entity, an alienated individual is but a fragment." (Tagore, 1986).

Here lies the solution to the intricate problem we have been confronted with while endeavouring to devise the way out of the bog of poverty, inequality and deprivation of the masses. As Tagore has emphasized, the masses are to be united making them free from dependence on the government help and also dependence on the mercy of extramundane entities like God. The spirit of confidence is to be inculcated in their minds that they, being united and dependent on their own power alone are capable of bringing about a new system of governance, economy and society characterized by freedom from poverty, inequality, deprivation and exploitation. We have still hope to make this world a place worthy to live in. 


\section{References}

Antonius, C. G. M. Robben (2007): Political Violence and Trauma in Argentina, University of Pennsylvania Press.

Arrow, K.J. (1951): Social Choice and Individual Values, New York, Wiley1963.

Basu, R. L. (1999): "Material Progress and Ethics: a Pilgrimage through Time" in The Culture Mandala (The Bulletin of the Center for East-West Cultural and Economic Studies, Bond University, Australia), Vol.4, No.1, December 1999-January 2000. [http://www.international-relations.com].

Basu, R. L. (2005): "Human Development Part 2: Ancient Kingship, Modern Politicians and the Problem of Corruption in India" in The Culture Mandala (The Bulletin of the Center for East-West Cultural and Economic Studies, Bond University, Australia), Vol.7, No.1, December 2005. [http://www.international-relations.com].

Black, J. K. (1986): Sentinels of Empire: The United States and Latin American Militarism, New York, Greenwood Press.

Drèze, J. and Sen, A. (1989): Hunger and Public Action, New Delhi, Oxford India Paperbacks, 1999.

Drèze, J., Sen, A. and Hussain, A. (eds.) (1995): The Political Economy of Hunger, New Delhi, Oxford India Paperbacks, 1999.

Engels, F. (1969): “The Principles of Communism”, Marx-Engels Selected Works, Volume-I, p. 81-97, Moscow, Progress Publishers.

Engels, F. (1975): Anti-Dühring, Moscow, Progress Publishers.

Engels, F. (1884): The Origin of the Family, Private Property and the State, Moscow, Progress Publishers, 1972.

Fitch, J. S. and Abraham F. L. (eds.) (1986): Armies and Politics in Latin America, New York, Holmes \& Meier.

Friedman, M. and Rose (1980): Free to Choose, London, Penguin.

Ghosh, A. (2001): The Glass Palace, HarperCollins. 
Hanumantha R., C. H. (1992): "Integrating Poverty Alleviation Programmes with Development Strategies" in Economic and Political Weekly, Vol. XXVII, No.48, November 28, Mumbai.

Hiraway, I. (1986): Abolition of Poverty in India, New Delhi, Vikash Publishing House.

Kangle, R. P. (1986): Kautiliya Arthasastra, Part-II [English translation], Delhi, Motilal Banarasidass.

Kant, I. (1795): "Perpetual Peace", in Kant's Principles of Politics, including his essay on Perpetual Peace, A Contribution to Political Science, (trans. W. Hastie), Edinburgh, Clark 1891.

Kosambi, D.D. (1981): The Culture and Civilization of Ancient India, New Delhi, Vikas Publishing House.

Laertius, D. (2001): Lives of Eminent Philosophers, Vol. I (tr. R. D. Hicks), Harvard University Press.

Marx and Engels (1848): Manifesto of the Communist Party, Moscow, Progress Publishers, 1975.

Marx, K. (1966): The Poverty of Philosophy, Moscow, Progress Publishers.

Marx, K. (1974): Economic and Philosophic Manuscript of 1848, Moscow, Progress Publishers.

McSherry, P. (2005): Predatory States: Operation Condor and Covert War in Latin America, Rowman \& Littlefield Publishers

Muqtada, M. (1990): The Elusive Target: An Evaluation of Target Group Approaches to Employment Creation in Rural Asia, ILO.

Nehru, J. (1981): The Discovery of India, New Delhi, Oxford University Press.

Plato (1901): The Republic, edited and translated by Benjamin Jowett, New York, P. F. Collier \& Son.

Sastri, K.A.N. (ed.) (1967): Age of the Nandas and Mauryas, Delhi, Motilal Banarasidass.

Sen, A. (1970): Collective Choice and Social Welfare, Amsterdam, North-Holland, 1979. 
Sen, A. (1981): Poverty and Famines, New Delhi, Oxford India Paperbacks, 1999.

Sen, A. (1984): Resources, Values and Development, New Delhi, Oxford India Paperbacks, 1999.

Sen, A. (1993): "Capability and Well-Being" in Martha C. Nussbaum and Amartya Sen (eds.), The Quality of Life, New York, Oxford University Press.

Sen, A. (2000): Development as Freedom, New Delhi, Oxford India Paperbacks, 1999.

Sinha, A. K. and Sen, R. K. (eds.) (2000): Economics of Amartya Sen, New Delhi, Deep and Deep Publications Pvt. Ltd.

Smith, A. (1759): The Theory of Moral Sentiments, London, A. Millar, Sixth edition, 1790.

Stalin, J. (1970): The Foundations of Leninism, Peking, Foreign Languages Press.

Tagore, R. (1986): "Samabaya Niti", in Rabindra Rachanavali, 125th Anniversary Edition, Vol. 14, P.313, Calcutta, Visva-Bharati Publishers (translated from Bengali by the author of this article).

Thapar, R. (1961): Asoka and the Decline of the Mauryas, New Delhi, Oxford University Press.

UNDP: Human Development Report, Various Issues.

World Bank: World Development Report, Various issues.

World Bank (1997): India: Achievements and Challenges in Reducing Poverty. 